\title{
Linguistic Disfluency in Retelling of Cause-Effect and Compare-Contrast Expository Discourses for Third to Fourth Graders from Multicultural Families
}

\author{
Hyojin Yoon, HeeCheong Chon \\ Department of Speech-Language Pathology, Chosun University, Gwangju, Korea
}

\begin{abstract}
초등 3 4학년 다문화가정 아동의 원인-결과와 비교-대조 설명담화 다시 말하기에 나타난 언어학적 비유창성 특성
\end{abstract}

윤 효 진·전 희 정

조선대학교 언어치료학과

\begin{abstract}
Purpose: The purpose of this study was to investigate the linguistic disfluencies of retelling in cause-effect and compare-contrast expository discourses for third to fourth graders from multicultural families. Methods: Participants were 15 children from multicultural families and 15 their grade-matched children from non-multicultural families. For two groups, there were no differences on standardized receptive and expressive vocabulary tests and nonverbal intelligence test. All participants were asked to retell two expository discourses after listening to two discourses with pictures. After transcribing the speech sample, linguistic disfluencies were categorized into filled pause, silent pause, repetition, and revision. Results: First, children from multicultural families produced significantly more linguistic disfluencies than those from non-multicultural families even though the total number of eojeols produced in two groups was similar. Second, children showed higher rates of disfluencies on compare-contrast, when compared to the cause-effect expository discourses. Filled pause was significantly more frequent in children from multicultural families than that from non-multicultural families and revision and pause were significantly prevalent in compare-contrast than cause-effect. Conclusion: The results demonstrate that children from multicultural families produced linguistic disfluencies more frequently on the retelling of the expository discourses and it may be relevant to the difficulty on linguistic and cognitive processing of expository discourses. Linguistic disfluency would be a useful clinical index to identify the problems on process of language production at the discourse level.
\end{abstract}

Key Words: Children from multicultural families, Linguistic disfluency, Expository discourse, Cause-effect, Compare-contrast.

Received: September 16, 2019 / Revised: September 27, 2019 / Accepted: September 29, 2019

Correspondence: HeeCheong Chon, Department of Speech-Language Pathology, Chosun University, 309 Pilmun-daero, Dong-gu, Gwangju 61452, Korea Tel: +82-62-230-7857 / Fax: +82-62-608-5401 / E-mail: hchon@chosun.ac.kr

\section{INTRODUCTION}

화자는 메시지를 구어로 전달하는 과정에서 발화의 내용 전 달과는 관련없는 '어', ‘음과 같은 간투사를 삽입하거나 이미 산 출한 음절이나 어절을 반복 혹은 수정하기도 하고, 발화 중 수

(c) This is an Open Access article distributed under the terms of the Creative Commons Attribution Non-Commercial License (https://creativecommons.org/licenses/by-nc/4.0) which permits unrestricted non-commercial use, distribution, and reproduction in any medium, provided the original work is properly cited.
초간의 휴지(silence pause) 다음에 이후 발화를 산출하기도 한다. 이렇게 지속적인 구어 산출의 흐름을 방해하는 외현적인 형태를 비유창성(disfluency)라고 한다(Yairi \& Seery, 2015). 비유창성은 크게 정상적인 비유창성과 비정상적인 비유창성 의 두 범주로 나눌 수 있으며, 이 중 정상적인 비유창성은 연령 과 상관없이 모든 화자의 발화에서 나타날 수 있다. Manning \& Shirkey(1981)는 정상적인 비유창성이 언어를 계획할 때 발 생하는 언어학적 비유창성이며, 이러한 비유창성으로 인해 화 
자는 자신이 산출하려는 발화를 체계화하는 시간을 벌 수 있 다고 하였다. 즉, 언어학적 비유창성은 산출할 메시지를 계획하 고 언어로 산출하는 언어 및 인지처리과정과 관련이 되어 있다. Levelt(1989)는 언어산출과정을 세 단계로 나눌 수 있으며, 이 단계 모두에서 비유창성이 나타날 수 있다고 하였다. 언어산출 과정을 자세히 살펴보면 우선 첫 단계는 개념 형성하기(conceptualization)로서 화자가 의사소통의 의도를 가지며, 메시지를 표상하는 단계이며, 두 번째 단계는 언어 형식을 구성하는 단 계(formulation)로 이미 형성된 메시지의 내용을 적절한 음운, 어휘와 구문의 언어 구조로 구성하는 단계이며, 마지막 단계는 조음 단계(articulation)로 화자가 조음기제를 사용하여 산출하 는 단계이다. 그리고 화자는 언어산출과정에서 자신이 계획한 발화를 지속적으로 모니터링하며 자신의 발화에 주의를 기울 인다고 보았다. 세 단계 모두에서 화자의 발화에 오류가 발생할 수 있으며, 오류가 내적 혹은 외적 모니터링을 통해 감지되면 언어산출과정을 중단하고 다양한 방식으로 발화를 수정하여 다시 산출한다. 이 중 내적으로 감지된 오류의 수정과정에서 나 타나는 언어학적 비유창성은 어, 음과 같은 간투사(filled pause) 의 삽입, 바로 전에 산출한 음절, 단어나 어절 등의 반복(repetition), 확인한 어휘 및 의미, 문법, 음운 오류의 수정(revision), 혹은 수 초 이상의 휴지(silent pause)이다. Loban(1976)은 비유 창성, 특히 언어학적 오류로 나타난 비유창성을 말의 길을 잃다 라는 의미로 미로(maze)라는 용어로 설명하였으며, 이러한 오류 들은 발화의 의미에는 영향을 미치지 않는 음절이나 단어 등이 다. 이 외에도 발화의 붕괴(speech disruption)나 방해(interruption) 혹은 중단(breakdown) 등으로 명명하기도 한다(Guo et al., 2008; Lim \& Hwang, 2009a).

연구자들은 각 언어산출과정에서 나타나는 비유창성의 유형 이 다르다고 주장하였는데, 간투사는 메시지를 전달하기 위해 언어를 계획하는 단계에서 오류를 확인했을 때 나타나며, 휴지 는 메시지를 계획하거나 문장 구성이나 어휘 인출에 어려움이 있을 때 나타난다고 보았다(Fraundorf \& Watson, 2013; Peach, 2013). 또한 반복은 어휘, 의미, 음운, 문법 및 구문 계획 및 인 출 단계에서 나타난 불확실성(uncertainty)을 의미하며, 자신의 발화를 내적으로 모니터링하는 과정으로 보았다(Fraundorf \& Watson, 2013; Thordardottir \& Weismer, 2002).

언어학적 비유창성은 성인 화자에서도 일정 정도 나타나기 는 하지만 언어발달이 급격하게 진행되는 시기의 아동이나 언 어장애를 동반한 아동의 발화에서 더 빈번하게 나타나면서 전 달하고자 하는 메시지의 효율성을 떨어뜨린다(Leadholm \& Miller, 1992; Thordardottir \& Weismer, 2002). 언어발달장애 아동이 보인 특성을 통해 언어학적 비유창성은 메시지를 계획 하고 산출할 때의 언어 및 인지처리과정에서 나타나는 산물이
며(Ellis \& Peach, 2009), 이는 언어발달장애 아동이 보이는 결 함으로 설명하고자 하였다. 특히 언어발달장애 아동은 자신이 전달하고자 하는 언어 목표와 자신이 실제 가지고 있는 언어능 력 간의 불일치를 경험할 때 언어학적인 비유창성이 나타난다 고 할 수 있다. 이는 요구-용량 모델(demands-capacities mod$\mathrm{el}$ 로도 설명할 수 있는데, 아동이 전달하고자 하는 메시지에 대한 스스로의 언어적인 요구(demand)가 그 메시지를 계획하 고 실행하는 아동의 언어능력인 용량(capacity)을 넘어섰을 때 발생한다고 보았다(Adams, 1990).

요구-용량 모델에 따르면 용량이 증가할 시 언어학적 비유창 성은 줄어든다고 가설을 세울 수 있는데, 이러한 가설은 연령 이 증가할수록 비유창성의 비율이 줄어든다는 선행연구들을 통해 증명되었다. 학령기 아동의 언어학적 비유창성을 살펴본 Lim \& Hwang(2009b)의 연구에서는 1학년에서 5학년으로 학 년이 올라갈수록 비유창성이 줄어들었다고 보고하였다. 언어능 력이 증가할수록 비유창성이 감소한다는 연구결과들은 언어 발달장애를 동반한 아동들은 언어학적 비유창성이 더 빈번하 게 나타날 수 있다는 것을 예측하게 해 준다. 이미 선행연구들 은 단순언어장애(specific language impairment), 주의력결핍 과잉행동장애(attention deficit and hyperactivity disorder, $\mathrm{ADHD})$, 그리고 외상성 뇌손상(traumatic brain injury) 등을 동반한 아동에게서 더 빈번한 언어학적 비유창성을 관찰하였 으며, 이를 통해 언어학적 비유창성이 언어발달장애 아동을 판 별하는 중요한 임상적 지표로서 활용될 수 있다고 하였다(Barron, 2018; German \& Newman, 2004; Leadholm \& Miller, 1992). 대표적인 연구로 Guo et al.(2008)은 4학년 단순언어장 애 아동의 이야기 발화에 나타난 비유창성을 분석하였으며, 단 순언어장애 아동이 연령을 일치시킨 일반 아동 집단보다 더 빈 번하게 발화의 중단이 나타나는 경향이 있으며, 이를 통해 언 어능력과 언어학적 비유창성 간의 부적 상관관계를 제시하였 다. 또한 메시지를 계획하고 실행하는 과정 역시 언어학적 비유 창성과 관련이 높다는 것을 $\mathrm{ADHD}$ 아동의 연구결과를 통해 보여주었다. Lim \& Hwang(2009a)은 초등 1 3학년 ADHD 아 동을 대상으로 하여 이야기 다시 말하기에 나타난 언어학적 비 유창성을 살펴보았으며, $\mathrm{ADHD}$ 아동과 일반 아동 집단 간에 언어능력에서 차이가 없음에도 불구하고 $\mathrm{ADHD}$ 아동에게서 더 빈번하게 비유창성이 나타났다는 점을 보고하면서 비유창 성은 언어 계획과 조직화, 실행기능 등의 전반적인 언어 및 인 지처리과정과 관련이 있음을 제시하였다.

최근의 아동 언어장애 연구들은 기질적 어려움으로 인한 언 어발달장애 아동뿐 아니라 환경적 요인으로 인해 언어발달 지 연을 보이는 다문화가정 아동의 특성에도 초점을 두고 있는데, 이들은 문화 및 언어적 차이로 인해 언어발달의 지연이 나타나 
는 경향이 있으며, 특히 언어 자극을 제공하는 주 양육자의 제 한된 언어능력이 아동의 발달과정에서 지속적으로 영향을 미 친다고 보았다. 일부 연구에서는 표준화된 언어 검사에서는 어 려움이 나타나지 않은 다문화가정의 아동들이 담화 산출에서 는 비다문화가정의 아동보다 어휘나 구문의 복잡도가 낮은 것 으로 나타나 다문화가정 아동의 담화 산출 특성을 구체적으로 살펴보는 것이 필요함을 보여주었다(Pae et al., 2010b). 다문화가 정 아동의 언어학적 비유창성을 살펴본 연구인 Kang et al.(2016) 의 연구에서도 공식 검사로 언어능력을 일치시켰음에도 불구하 고 이야기 다시 말하기에 나타난 비유창성은 다문화가정의 아 동이 비다문화가정 아동보다 더 빈번한 것으로 나타났다. 이는 학령기 아동의 언어 평가에서 담화 수준의 평가와 언어산출과 정을 전반적으로 살펴볼 수 있는 언어학적 비유창성이 유용함 을 확인해 주는 결과라고 할 수 있다.

언어학적 비유창성은 언어학적 복잡성이 높아질 때 증가한 다는 것을 고려한다면 담화 장르의 복잡성도 영향을 미친다고 예측할 수 있다. 이미 선행연구들은 언어학적 비유창성은 대화 보다 이야기담화에서 더 빈번하며, 또한 이야기담화보다는 담화 적 복잡성이 더 높은 설명담화에서 더 빈번하다는 연구결과들 을 제시하였다(Lim \& Hwang, 2009b; Navarro-Ruiz \& RalloFabra, 2001; Scott \& Windsor; 2000; Wagner et al., 2000). 이 는 대화보다 이야기담화에서, 이야기담화보다 설명담화에서 저 빈도 어휘의 사용이 높으며, 구문 구조의 복잡성도 더 높기 때 문으로 설명할 수 있다. 게다가 설명담화는 어떤 구체적인 개념 에 대한 설명이나, 선행하는 사건과 후행하는 결과 등에 대한 논리적 인과관계를 이해해야 하는 등 높은 수준의 인지적 처리 가 요구되기 때문에 언어학적 비유창성이 더 빈번하게 나타날 수 있다. 설명담화의 이해와 산출과정이 더 높은 언어 및 인지처 리과정을 요구하는 또 다른 이유는 동일한 구조를 가진 이야기 담화와 달리 설명담화는 유형이 다양하며, 각 유형의 구조에 대 한 인식력이 있어야만 효과적인 담화 산출이 가능하기 때문이 다. 초등 교과과정에서 수록된 설명담화의 유형은 대표적으로 수집, 비교-대조, 원인-결과, 문제-해결 등이 있다(Kim, 2004). 저학년의 교과과정에서는 수집 구조, 중학년에서는 비교-대조나 원인-결과가 빈번하게 나타나며, 고학년으로 갈수록 다소 복잡 한 설명담화 구조인 문제-해결의 설명담화 구조가 포함된다. 설 명담화 유형에 따른 차이를 살펴본 연구들에 따르면 설명담화 유형에 따라 어휘나 구문의 다양성이나 복잡도가 다르게 나타 났으며(Kim \& Yoon, 2018; Nippold et al., 2007), 이러한 결과 들을 통해 설명담화의 유형에 따라 언어학적 비유창성이 다르 게 나타날 수 있다는 것을 유추할 수 있다. 특히 이전의 선행연 구들은 대화와 이야기담화, 이야기담화와 설명담화 등으로 담 화 장르 간의 언어학적 비유창성을 살펴본 연구들이 대부분이
기 때문에 설명담화 유형에 따른 언어학적 비유창성을 살펴보 는 것이 필요한 시점이다.

종합하면 언어발달이 진행되는 시기의 아동들은 담화산출 과정에서 메시지를 계획하거나 그 메시지에 대한 언어를 구성 하고, 이를 산출하는 과정에서 언어학적 비유창성을 경험할 수 있으며, 언어학적 비유창성의 비율은 언어능력에 따라, 그리고 담화 구조의 복잡성에 따라 다르게 나타날 수 있다. 하지만 학 령기 교과과정에서 설명담화의 비중이 높고, 다양한 설명담화 유형이 포함되어 있음에도 불구하고 이러한 설명담화의 유형에 따른 언어학적 비유창성을 살펴본 연구들은 제한적이다. 또한 다문화가정의 아동은 어휘나 구문을 살펴보는 공식 검사에서 어려움이 없음에도 불구하고 이야기나 설명담화와 같은 담화 산 출에서는 수행력이 낮은 것으로 나타나 이러한 특성이 담화산출 과정의 언어학적 비유창성에서도 나타나는지를 살펴봄으로써 다문화가정 아동의 언어학적 특성을 면밀하게 확인하는 것이 필요하다.

따라서 본 연구는 다문화가정의 아동과 비다문화가정의 아 동을 대상으로 하여 두 설명담화 유형에 나타난 언어학적 비유 창성 특성을 살펴보고자 한다. 특히 교과과정에서 설명담화가 본격적으로 나타나는 초등 3 4학년 시기의 아동을 대상으로 살펴볼 것이며, 이때 교과과정에서 빈번하게 나타나는 설명담화 유형인 원인-결과와 비교-대조를 중심으로 하여 두 담화의 다 시 말하기에서 나타난 언어학적 비유창성 특성을 비교해 보고 자 한다.

\section{MATERIALS AND METHODS}

\section{연구 대상}

본 연구에 참여한 아동은 광주·전라 지역의 초등 3-4학년 아동으로 인지 및 언어발달에 어려움이 없는 다문화가정의 아 동 15 명, 비다문화가정의 아동 15 명(총 30 명)이다. 우선 다문화 가정 아동의 선정기준은 1) 어머니가 외국인이고 아버지는 한 국인인 다문화가정이며, 2) 한국에서 출생하여 거주하고 있으 며, 3) 한국어를 단일어로 사용하고 있는 아동이다. 어머니의 출신국가는 베트남 $73 \%$, 중국 $13 \%$, 캄보디아 $7 \%$, 필리핀 7\%였 다. 연구에 참여한 아동들은 수용·표현어휘력검사(Receptive \& Expressive Vocabulary Test, REVT) 결과 수용 및 표현 어 휘 모두 -1 표준편차 이상인 아동으로 선정하였다(Kim et al., 2009). 또한 인지능력에는 어려움이 없는 아동으로 선정하기 위해 한국판-비언어성지능검사-2(Korean Comprehensive Test of Nonverbal Intelligence-2, K-CTONI-2)를 사용하였 으며(Park, 2014), 검사결과 비구어성 지능 지수가 80 이상인 아 동만 본 연구에 참여하였다. 본 연구에 참여한 아동의 연령, $\mathrm{K}-$ 
Table 1. Participants' information in children from multicultural and non-multicultural families

\begin{tabular}{lccc}
\hline & $\begin{array}{c}\text { Children from } \\
\text { MCF }\end{array}$ & $\begin{array}{c}\text { Children from } \\
\text { non-MCF }\end{array}$ & p-value \\
\hline Age (month) & $111.87(7.34)$ & $109.33(7.74)$ & 0.366 \\
K-CTONI-2* $^{*}$ & $102.87(15.31)$ & $106.07(13.20)$ & 0.545 \\
REVT-receptive $^{\dagger}$ & $100.53(16.25)$ & $108.00(16.04)$ & 0.216 \\
REVT-expressive $^{\dagger}$ & $93.20(12.93)$ & $101.53(16.10)$ & 0.129 \\
\hline
\end{tabular}

*standard score, ${ }^{\dagger}$ raw score. MCF: multicultural families, K-CTONI-2: Korean Comprehensive Test of Nonverbal Intelligence-2, REVT: Receptive \& Expressive Vocabulary Test

CTONI-2, REVT 평균은 Table 1과 같다. 두 집단 간에 차이 가 있는지를 살펴보기 위해 독립표본 $t$-test를 실시한 결과 모 든 항목에서 집단 간 차이가 없는 것으로 나타났다.

\section{연구 절차}

\section{검사 도구}

본 연구에서는 아동에게 그림을 제시하면서 녹음된 설명담 화를 들려준 후 그림을 다시 보면서 설명담화를 재차 말하도록 요구하는 과제를 실시하였다. 설명담화의 주제나 포함된 내용 이 어려울 경우 산출하는 발화의 양이 적고, 구문 복잡도도 낮 을 수 있다는 연구결과에 따라 초등 3 4학년 수준에 맞도록 주제, 어휘, 구문 복잡도를 고려하여 글을 구성하였다(Chung, 2014). 본 연구에서는 학령기 다문화가정 아동을 위한 교육 교 재인 '함께 읽고 말해요'에서 ‘추석과 설날'이라는 주제의 비교대조와 '빙하가 녹고 있다’는 주제의 원인-결과의 두 설명담화 를 선정하였으며(Pae et al., 2010a), 이를 초등 3 4학년의 언어 능력에 맞게 수정하였다. 또한 두 담화에 나타난 언어학적 비유 창성을 비교하기 위해 두 담화의 어휘 난이도, 구문 길이 및 구 문 복잡성은 비슷하게 조절하였다. 두 설명담화에서 사용한 어 휘는 ‘등급별 국어 교육용 어휘’에서 1 3등급이며(Kim, 2003), '초등학교 교과서 어휘 조사연구'의 초등 1 3학년 어휘가 $90 \%$ 이상 차지하도록 하였다(Kim, 2009). 두 담화는 평균 22문장, 236 어절로 구성되었으며, T-unit당 평균 단어 길이는 $10.75, \mathrm{~T}-$ unit당 평균 형태소 길이는 20.39이다. 또한 글을 제작한 후 다 시 말하기에 대한 인지적 부담을 줄이기 위해 글의 내용에 해당 하는 그림을 제작하였다. 그림은 초등 3 4학년 수준에 적절하게 컬러로 제작하였으며, 각 담화를 9개의 순서 그림(sequencing picture)으로 구성하였다.

제작한 글과 그림은 국어국문학 교수 1 인, 언어병리학 교수 1 인, 언어병리학 박사 학위를 소지한 언어재활사 2 인에게 의뢰하 여 주제 및 내용, 그림의 적절성, 어휘 및 구문적 난이도에 대한 내용 타당도를 실시하였다. 내용 타당도 지수를 Likert 5점 척도
로 실시한 결과, 비교-대조의 설명담화 글과 그림은 평균 4.65점, 원인-결과의 설명담화는 평균 4.44점으로 나타났다.

\section{검사 실시}

본 연구는 대상자 선정을 위해 K-CTONI-2, REVT를 실시 한 후 본 연구를 위한 검사를 실시하였다. 순서 효과를 배제하기 위해 두 설명담화는 무작위로 선정하여 제시하였으며, 다시 말 하기 과제 수행 시 전사를 위해 아동의 발화를 모두 녹음하였 다. 아동에게 "선생님이 지금부터 그림을 보여주면서 이야기를 들려줄 거예요. 다 듣고 나서 그림을 보면서 기억나는 것을 선 생님한테 다시 자세히 말해주세요.”라고 지시문을 제시하였다.

\section{자료 분석}

본 연구는 Kang et al.(2016)과 Chung(2014), 한국어 이야기 평가의 비유창성 분석을 참고로 하여(Kwon et al., 2018), 비유 창성 유형을 분류하였으며 선행연구에 따라 분석의 단위는 어 절을 기준으로 하였다. 비유창성 유형은 간투사, 반복, 수정, 휴 지로 분석하였으며, 수정은 다시 어휘 및 의미적 변화를 위한 수정, 문법적 변화를 위한 수정, 음운적 변화를 위한 수정으로 분석하였다. 비유창성 유형에 대한 자세한 분석 기준은 $\mathrm{Ap}-$ pendix에 제시하였다.

발화의 양에 따른 비유창성 빈도를 통제하기 위해 비유창성 비율을 계산하였다. 총 비유창성 비율은 총 비유창성 빈도를 아동이 산출한 총 어절 수로 나눈 후 100 을 곱하여 계산하였 다(총 비유창성 비율 $=$ 총 비유창성 빈도 $/$ 총 어절 수 $\times 100)$. 또한 비유창성 유형에 따른 상대적 비율을 측정하기 위해 각 비유창성 유형의 빈도를 총 어절 수로 나눈 후 100 을 곱하였다 (각 비유창성 유형의 비율 $=$ 유형별 비유창성 빈도 / 총 어절 수 $\times 100)$.

수집한 자료 중 $30 \%$ 를 무작위로 선정하여 본 연구의 제 1 저 자와 언어치료학 석사과정 대학원생이 비유창성 유형을 분석 한 후 평가자 간 신뢰도를 산출한 결과 $91.2 \%$ 의 일치율이 나타 났다.

\section{통계 분석}

수집된 자료는 SPSS version 25.0 (IBM Corp., Armonk, NY, USA) 소프트웨어를 이용하여 통계 분석을 실시하였다. 본 연구에서는 다문화가정 아동과 비다문화가정 아동의 설명담화 유형에 따른 비유창성 비율(총 비유창성 비율, 비유창성 유형 비율)을 각각 살펴보기 위해 두 집단을 집단 간 변인으로, 설명 담화 유형(원인-결과, 비교-대조)을 집단 내 변인으로 하여 이요인 혼합 분산분석[two-way mixed-design analysis of variance (ANOVA)]을 실시하였다. 


\section{RESULTS}

초등 3 4학년의 다문화가정 아동과 비다문화가정 아동의 설명담화 유형에 따른 총 어절 수와 비유창성 비율을 살펴본 결과 Table 2에서 보는 바와 같이 두 집단 간에 산출한 총 어절 수의 평균에는 차이가 없는 것으로 나타났다. 원인-결과의 설 명담화에서 다문화가정의 아동과 비다문화가정의 아동은 모 두 약 84어절을 산출했으며, 비교-대조 설명담화에서는 다문 화가정의 아동은 약 79어절, 비다문화가정의 아동은 약 76 어 절을 산출한 것으로 나타났다. 반면 비유창한 어절 수를 총 어 절 수로 나눈 후 100 을 곱한 총 비유창성 비율에서는 다문화가 정 아동의 평균이 상대적으로 높은 것으로 나타났다. 원인-결 과 담화에서 다문화가정 아동의 비유창성 비율은 $27.99 \%$ 인 반 면, 비다문화가정 아동의 비유창성 비율은 $15.76 \%$ 로 나타났다.
비교-대조에서도 유사한 패턴이 나타났는데 다문화가정 아동 의 비유창성 비율은 $35.62 \%$ 인 반면, 비다문화가정의 아동은 $24.95 \%$ 로 나타났다.

초등 3 4학년 다문화가정 아동과 비다문화가정 아동 간에 설명담화 유형에 따라 비유창성 비율에 차이가 있는지를 살펴 보기 위해 two-way mixed-design ANOVA를 실시한 결과는 Table 3과 같다. 집단과 설명담화 유형 간의 상호작용 효과는 나 타나지 않았으며, 집단 $(\mathrm{F}=9.149, p=0.005)$ 과 설명담화 $(\mathrm{F}=$ $12.656, p=0.001)$ 에 따른 주 효과가 있는 것으로 나타났다. 즉, 다문화가정 아동의 비유창성 비율이 통계적으로 유의하게 높 은 것으로 나타났고, 비교-대조의 설명담화 유형에서 비유창성 비율이 더 높은 것으로 나타났다.

각 집단의 담화 유형에 따른 비유창성 유형의 비율과 전체 비유창성 유형의 비율은 Table 4와 같다. 다문화가정과 비다문

Table 2. Descriptive statistics (mean and standard deviation) of total number of eojeol and rates of linguistic disfluency for two groups and types of expository discourses

\begin{tabular}{|c|c|c|c|c|c|c|}
\hline \multirow[b]{2}{*}{ Group } & \multicolumn{2}{|c|}{ Cause-effect } & \multicolumn{2}{|c|}{ Compare-contrast } & \multicolumn{2}{|c|}{ Total } \\
\hline & $\begin{array}{c}\text { Total number } \\
\text { of eojeol }\end{array}$ & $\begin{array}{c}\text { Rates of linguistic } \\
\text { disfluency (\%) }\end{array}$ & $\begin{array}{c}\text { Total number } \\
\text { of eojeol }\end{array}$ & $\begin{array}{c}\text { Rates of linguistic } \\
\text { disfluency }(\%)\end{array}$ & $\begin{array}{c}\text { Total number } \\
\text { of eojeol }\end{array}$ & $\begin{array}{c}\text { Rates of linguistic } \\
\text { disfluency (\%) }\end{array}$ \\
\hline Children from MCF & $84.20(34.04)$ & $27.99(12.90)$ & $79.40(18.16)$ & $35.62(17.51)$ & $81.80(5.67)$ & $31.81(13.29)$ \\
\hline Children from non-MCF & $84.87(29.71)$ & $15.76(9.54)$ & $76.47(21.66)$ & $24.95(6.74)$ & $80.67(23.88)$ & $20.03(7.13)$ \\
\hline Total & $84.53(31.39)$ & $21.88(12.76)$ & $77.93(19.70)$ & $29.95(14.25)$ & $81.23(22.56)$ & $25.92(12.07)$ \\
\hline
\end{tabular}

MCF: multicultural families

Table 3. Analysis of variance for rates of linguistic disfluency according to groups and types of expository discourses

\begin{tabular}{lccccc}
\hline \multicolumn{1}{c}{ Source } & Sum of squares & $\mathrm{df}$ & Mean squares & $\mathrm{F}$ & $p$-value \\
\hline Group & $2,082.723$ & 1 & $2,082.723$ & 9.149 & 0.005 \\
Types of expository & 977.966 & 1 & 977.966 & 12.656 & 0.001 \\
Group $\times$ types & 3.018 & 1 & 3.018 & 0.039 & 0.845 \\
\hline
\end{tabular}

Table 4. Mean rates (standard deviation) of each linguistic disfluency type in two groups

\begin{tabular}{llccc}
\hline \multicolumn{1}{c}{ Types of disfluencies } & \multicolumn{1}{c}{ Groups } & Cause-effect & Compare-contrast & Overall mean percentage \\
\hline Filled pause & Children from MCF & $8.40(6.65)$ & $10.70(8.00)$ & $9.55(6.53)$ \\
& Children from non-MCF & $3.91(1.48)$ & $4.31(3.49)$ & $4.11(4.39)$ \\
Silent pause & Children from MCF & $0.82(1.48)$ & $1.61(3.01)$ & $1.26(2.12)$ \\
& Children from non-MCF & $0.70(1.31)$ & $2.37(4.09)$ & $1.54(2.51)$ \\
Repetition & Children from MCF & $9.20(5.22)$ & $9.49(5.87)$ & $9.35(6.42)$ \\
& Children from non-MCF & $5.36(4.76)$ & $5.87(3.52)$ & $5.62(3.45)$ \\
Total revision & Children from MCF & $7.71(3.34)$ & $8.90(5.43)$ & $8.31(4.84)$ \\
Revision for semantic and lexical change & Children from MCF & $6.06(5.32)$ & $6.76(5.71)$ & $6.24(2.92)$ \\
& Children from non-MCF & $3.04(2.49)$ & $6.89(3.32)$ & $6.41(4.37)$ \\
Revision for morphosyntactic change & Children from MCF & $1.27(1.17)$ & $1.91(2.39)$ & $4.96(2.51)$ \\
& Children from non-MCF & $0.63(1.03)$ & $1.71(1.77)$ & $1.59(1.47)$ \\
Revision for phonological change & Children from MCF & $0.38(1.17)$ & $0.22(0.48)$ & $1.17(0.91)$ \\
& Children from non-MCF & $0.20(0.58)$ & $0.00(0.00)$ & $0.30(0.59)$ \\
\hline
\end{tabular}

MCF: multicultural families 
화가정 아동이 두 설명담화에서 산출한 전체 비유창성 유형의 비율을 살펴본 결과, 다문화가정의 아동은 간투사 비율이 평균 9.55\%로 가장 높았으며, 그 다음으로 반복이 $9.35 \%$, 그 다음에 총 수정은 $8.31 \%$, 휴지는 $1.26 \%$ 로 가장 낮게 나타났다. 반면 비다문화가정의 아동 집단에서는 총 수정이 평균 $6.24 \%$ 로 가장 높은 비유창성 유형으로 나타났으며, 그 다음엔 반복이 $5.62 \%$ 로 나왔으며, 간투사 비율은 $4.11 \%$ 로 나타났다. 다문화가정과 마찬가지로 휴지는 평균 $1.54 \%$ 로 가장 낮게 나타났다.

집단을 집단 간 변인으로, 설명담화 유형을 집단 내 변인으 로 하여 각 비유창성 유형의 비율에 차이가 있는지를 살펴보기 위해 two-way mixed-design ANOVA를 실시한 결과 간투사, 휴지, 반복, 총 수정, 어휘 및 의미적 변화를 위한 수정, 문법적 변화를 위한 수정, 음운적 변화를 위한 수정 모두에서 상호작용 효과는 관찰되지 않았다. 간투사의 비율은 다문화가정의 아동 이 통계적으로 유의하게 높게 나타났으며 $(\mathrm{F}=7.159, p=0.012)$, 총 수정 비율 $(\mathrm{F}=5.495, p=0.026)$ 과 휴지 비율 $(\mathrm{F}=5.962, p=$ 0.021)은 비교-대조에서 더 빈번하게 나타나면서 담화 유형 간 차이만 있는 것으로 나타났다.

\section{DISCUSSIONS}

본 연구는 초등 3 4학년 다문화가정 아동과 비다문화가정 아동을 대상으로 원인-결과와 비교-대조의 설명담화 다시 말 하기에 나타난 언어학적 비유창성 특성을 살펴보고자 하였다.

다문화가정 아동과 비다문화가정 아동의 설명담화 다시 말 하기에 나타난 총 어절 수는 차이가 없었으며, 두 설명담화 유 형 간에도 총 어절 수의 차이는 없는 것으로 나타났다. 그럼에 도 불구하고 총 비유창성 빈도를 총 어절 수로 나누고 100을 곱한 총 비유창성 비율은 두 집단과 두 담화 유형 모두에서 차 이가 있는 것으로 나타났다.

우선 두 집단 간의 차이를 살펴보면 다문화가정의 아동이 그 림을 보면서 설명담화를 들은 후 다시 말하는 과제에서 비다문 화가정의 아동과 유사한 발화의 양(어절 수)을 산출했지만, 이 과정에서 나타난 비유창성 비율은 더 높은 것으로 나타났다. 본 연구에서는 어휘력 검사를 통해 두 집단의 동질성을 확보하 였지만 이러한 어휘의 양적 측면이 설명담화산출이라는 좀 더 높은 수준의 언어와 인지처리과정을 반영하는 데에는 한계가 있는 것으로 해석할 수 있다. 여러 선행연구에서도 공식 검사 를 통해 어휘나 구문능력을 일치시켰음에도 불구하고 담화산 출에서는 다문화가정의 아동과 비다문화가정의 아동 간에 차 이가 나타난 연구결과들이 있다. Kang et al.(2016)의 연구에서 는 어휘와 구문 의미 이해능력으로 언어능력을 일치시켰지만 다 문화가정의 아동이 구문 복잡도가 낮고, 비유창성 비율은 높은
것으로 나타났으며, 이야기 산출능력을 살펴본 Pae et al.(2010b) 의 연구에서도 구문 의미 이해능력으로 언어능력을 일치시켰지 만 전체적인 이야기 내의 주요 사건, 이에 대한 시도와 결과 등 의 중요 내용과 전체 주제 유지를 살펴보는 이야기 구성력에서 다문화가정 아동의 수행능력이 낮은 것으로 나타났다. 본 연구 결과와 이전 선행연구에 나타난 결과들은 개별적인 단어나 문 장 수준의 언어능력과 담화의 산출과정에서 필요한 처리능력 의 차이에 기인한다고 볼 수 있다.

담화를 이해하고 산출하는 과정은 표면적 수준의 어휘와 구 문에 대한 지식뿐 아니라 자신의 배경지식과 글의 정보를 통합 하고, 추론과정을 통해 글에 제시되지 않은 정보를 유추하고 자기 모니터링 과정을 통해 내용의 이해를 점검하여 전반적인 내용을 통합해 심적 표상을 구축한 후 다시 말해야 하는 과정 을 필요로 하기 때문에(Kim \& Yoon, 2018), 더 높은 수준의 언 어 및 인지처리과정을 요구한다. 특히 설명담화는 대화, 이야기 등의 다른 담화와 비교하였을 때 문어(written language)적 특 성이 강하며, 객관적 정보나 개념을 전달하기 위해 저빈도 어휘 의 사용이 높고 복잡한 구문 복잡성을 가지는 특성이 있다(Lee \& Jung, 2013). 또한 설명담화는 이야기와 같이 동일한 구조(이 야기 문법)를 가지는 것이 아니라 설명담화의 유형, 즉, 비교-대 조, 원인-결과, 문제-해결 등에 따라 구조가 다르기 때문에 이 에 대한 구조의 인식력(awareness of text structure)도 필요하 다. 그래서 설명담화를 이해하고 표현하는 능력은 청소년기를 거쳐 성인기까지도 지속적으로 발달한다(Englert \& Hiebert, 1984; Ray \& Meyer, 2011). 본 연구의 결과를 통해 다문화가정 의 아동은 표면적 어휘의 양적 수준에서는 또래 비다문화가정 의 아동과 비교하여 어려움이 없지만 복잡하고 높은 수준의 인지처리과정을 필요로 하는 담화산출과정에서는 어려움이 발 생할 수 있다는 해석이 가능하며(Lundine et al., 2018; Westby et al., 2010), 담화 산출에 나타난 언어학적 비유창성을 분석함 으로써 다문화가정 아동의 언어능력을 세밀하게 분석할 수 있 다는 것을 보여주었다.

총 비유창성 비율은 집단 간 차이뿐 아니라 두 설명담화의 유형 간에도 차이가 있는 것으로 나타났는데, 원인-결과의 설 명담화보다는 비교-대조의 설명담화에서 두 집단 모두 더 빈번 하게 비유창성이 나타났다. 더 복잡한 담화 구조에서 언어 및 인지적 부담이 증가하면 언어학적 비유창성이 증가한다고 보았 기 때문에(Lim \& Hwang, 2009b), 담화의 구조가 상대적으로 더 복잡한 원인-결과 구조에서 비유창성의 비율이 높을 것으 로 예측했던 것과는 상이한 결과이다. 이러한 연구결과는 본 연구에서 사용한 설명담화의 주제와 관련이 있는 것으로 해석 할 수 있다. 각 설명담화에서 아동들이 산출한 발화의 내용을 살펴본 결과, 비교-대조에서는 추석과 설날의 날짜, 계절, 음식, 
전통놀이 등의 공통점과 차이점에 대한 내용을 산출해야 하는 데 추석과 설날의 공통점과 차이점을 반대로 설명하면서 높은 간투사와 반복, 수정 등의 비유창성을 보인 것으로 나타났다. 즉, 추석을 설명할 때 설날의 날짜나 특성을 말한 후 이를 수정 하거나 반복하였으며, 반대로 설날을 설명해야 할 때 다시 추석 의 날짜나 음식, 놀이 등을 말하면서 비유창성이 빈번하게 나 타났다. 반면 원인-결과에서는 지구 온난화의 원인과 지구 온 난화로 인해 나타난 결과들에 대한 내용이었다. 또한 본 연구 에서는 그림을 제시하면서 이야기를 들려주고, 그림을 보면서 다시 말하도록 요구하는 과제를 실시하였기 때문에 상대적으 로 담화의 구조가 복잡했던 원인-결과 구조에서도 인지적 부 담이 줄었고, 아동들은 그림에 나타난 원인과 결과들을 순서적 으로 산출할 수 있었던 것으로 보인다. 이러한 설명담화의 주제 와 과제 제시 방법이 두 설명담화 간 총 비유창성 비율의 차이 를 야기한 것으로 설명할 수 있을 것이다.

두 아동 집단과 설명담화 유형에서 빈번하게 나타난 비유창 성 유형을 살펴본 결과 다문화가정의 아동은 간투사(13.75\%) 를 가장 빈번하게 산출하였으며, 그 다음으로 반복(9.35\%), 수 정(8.31\%), 휴지(1.23\%) 순으로 산출하였다. 반면 비다문화가정 의 아동은 수정(6.24\%)이 가장 빈번하게 산출한 비유창성 유 형이었으며, 그 다음으로 반복(5.62\%)과 간투사(4.11\%), 휴지 (1.54\%) 순으로 나타났다.

이 중 간투사는 다문화가정의 아동이 비다문화가정의 아동 보다 유의하게 많이 산출한 것으로 나타났다. 전술하였듯이 두 집단 간에 수용 및 표현 어휘능력에서 차이가 나타나지 않았음 에도 불구하고 총 비유창성 비율에 차이가 있는 것으로 나타났 는데, 이러한 두 집단 간의 차이를 야기한 비유창성 유형 중 하 나가 간투사이다. 이는 다문화가정 아동의 설명담화 다시 말하 기 과제 수행 시 가장 빈번한 비유창성 유형이 간투사였다는 Kang et al.(2016)의 연구와도 일치하는 결과이다. 간투사는 언 어적으로 문장을 계획하는 단계, 즉, 다음에 나올 정보에 대한 어휘를 선택하고 구문을 표상하여 산출을 준비하는 과정에서 어려움이 나타났을 때 일종의 시간을 벌기 위한 전략으로 사용 하는 비유창성 유형이다(Fraundorf \& Watson, 2013). 또한 새 롭게 제시하는 개념이나 내용이 불확실하거나 스스로 충분히 이해하지 못했을 때에도 나타난다(Kang et al., 2016). 설명담 화는 정보나 사건, 개념 등을 목적에 맞게 설명하기 위해 공통 점이나 차이점을 비교하거나 원인과 결과를 인과적 순서에 맞 게 나열해야 하기 때문에 언어적 복잡성이 높고 인지적 부담도 높은 담화 과제로, 다문화가정의 아동은 원인-결과와 비교-대 조의 설명담화에서 다음에 올 새로운 개념과 문장을 계획하는 단계에서 특히 어려움을 보이면서 간투사의 사용이 빈번하였다 고 설명할 수 있을 것이다.
반면 비다문화가정의 아동 집단에서는 수정이 가장 빈번하 게 산출한 비유창성 유형인 것으로 나타났다. 수정은 자기 모니 터링(self-monitoring)을 의미하는 것으로 자신이 산출하고 난 후 오류를 확인하고 자발적으로 수정하는 전략이다(Rispoli et al., 2008). 즉, 자기 모니터링 과정을 통해 의도된 메시지와 자 신이 실제로 산출한 메시지를 비교하는 과정에서 오류를 감지 했을 때 이러한 전략을 사용하는 것이다(Levelt, 1989). 수정은 언어능력을 반영하면서 연령이 증가할수록 더 빈번하게 나타나 는 전략 중 하나로(Lim \& Hwang, 2009b), 비다문화가정의 아 동은 담화산출과정에서 자신의 말을 수정함으로써 발화를 명료 하게 하고자 했던 것으로 해석할 수 있다. 수정을 어휘 및 의미 적 변화, 문법적 변화, 음운적 변화의 세 유형으로 살펴본 결과, 어휘 및 의미적 변화를 위한 수정(4.96\%)이 가장 빈번하였고, 그 다음에 문법적 변화(1.17\%)가 빈번하게 나타났던 반면, 음운 적 변화는 두 집단 모두에서 $1 \%$ 미만으로 거의 나타나지 않았 다. Lim \& Hwang(2009b)은 학령기 아동은 음운능력과 문법 및 구문능력이 안정화되는 시기이기 때문에 음운적 변화나 문 법적 변화를 위한 수정 전략은 거의 사용하지 않는 반면 의미 적 명료화를 위해 어휘 및 의미적 변화를 위한 수정 전략을 빈 번하게 사용한다고 설명하였다. 본 연구에서도 각 설명담화의 주제에 맞게 내용을 명료화하는 과정에서 어휘를 수정하거나 의미를 명확하게 하기 위한 어휘 및 의미 수정이 빈번하게 나타 났다고 해석할 수 있을 것이다.

두 집단 모두에서 반복은 두 번째로 빈번한 비유창성 유형인 것으로 나타났다. 반복은 이미 산출한 음소, 음절이나 단어 등 의 단위를 단순히 되풀이함으로써 다음에 올 발화의 산출을 지연하는 전략이다. 반복도 간투사와 비슷하게 다음에 올 내용 을 계획하는 단계에서 문장을 구성하거나 어휘 등을 인출하는 과정에 어려움이 발생했을 때 나타나며, 계획의 지연이 발화의 유창성을 방해할 때 그 부분을 되풀이함으로써 마치 발화가 유창한 것처럼 보이도록 하는 유형인데(Fraundorf \& Watson, 2013), 초등 3 4학년의 아동들은 설명담화의 내용을 계획하고 산출하는 과정에서 반복이 빈번하게 나타났다고 볼 수 있다.

마지막으로 휴지는 두 집단 모두 1 2\%로 낮게 산출하였다. 본 연구에서는 5초 이상의 휴지를 보였을 때 휴지로 간주하였 기 때문에 언어발달의 어려움이 없는 초등 3 4학년의 아동은 거의 사용하지 않는 것으로 나타났다. 휴지 비율이 가장 낮게 나타난 본 연구의 결과는 학령기 단순언어장애 아동, $\mathrm{ADHD}$ 아동, 다문화가정의 아동과 일반 아동을 비교한 연구들과 일치 하는 결과이다(Kang et al., 2016; Lee et al., 2010; Lim \& Hwang, 2009b). 휴지는 간투사와 마찬가지로 메시지를 계획하 고, 이러한 메시지에 대해 의미와 구문 정보를 통합하여 문장 으로 산출하는 과정에서 어려움에 직면했을 때 보인다. 하지만 
담화 산출 중 휴지는 발화의 중단으로 대화자로서의 역할을 잃 어버릴 수 있기 때문에 휴지보다는 간투사를 더 빈번하게 사용 하는 경향이 있다(Guo et al., 2008).

비유창성 유형 중 수정과 휴지는 비교-대조의 담화에서 통 계적으로 유의할 만큼 더 빈번하게 나타났다. 비교-대조 담화 는 추석과 설날에 대한 배경지식과 새로운 정보를 통합하고, 두 명절의 공통점과 차이점을 나열하면서 처리해야 하는 과정 이 요구된다. 특히, 두 명절의 공통점과 차이점을 나열해야 하 는 메시지 계획 단계에서의 어려움이 휴지와 같은 비유창성을 야기했다고 예측할 수 있다. 또한 공통점과 차이점을 논리적이 며 순서적으로 나열해야 하는 복잡한 언어 및 인지처리과정에 서 어려움이 나타났고, 두 명절에 대해 친숙하게 알고 있기 때 문에 빠르게 자신의 오류를 확인하고 수정하는 전략을 사용했 다고 설명할 수 있을 것이다.

비유창성은 화자로서 발화를 산출하는 과정에서 발화의 중 단 혹은 붕괴를 해결하고자 하는 전략이다(Clark \& Fax Tree, 2002; Postma \& Kolk, 1993). 본 연구에서는 어휘의 양적 측면 에서 다문화가정의 아동과 비다문화가정의 아동이 차이가 없 었으며, 산출한 설명담화의 총 어절 수에서도 차이가 없었음에 도 불구하고 다문화가정의 아동에게서 더 빈번한 언어학적 비 유창성이 나타난 것을 확인할 수 있었다. 이러한 차이는 다문 화가정의 아동은 담화의 이해와 산출이라는 높은 수준의 언어 및 인지적 부담이 요구되는 과제에서는 어려움을 보일 수 있다 는 해석을 가능하게 한다. 다문화가정의 아동 언어 평가 시 공 식 검사 사용의 제한점이 있으며, 이러한 제한점은 담화 산출 의 특성을 살펴봄으로써 해결할 수 있다는 선행연구와 공식 검 사에서 어려움이 없음에도 불구하고 담화 산출에서는 비다문 화가정의 아동과 차이가 있었다는 여러 연구결과들은 다문화가 정 아동의 언어 평가에서 공식 검사뿐 아니라 담화 산출의 특성 을 함께 살펴보는 것이 필요함을 강조할 수 있을 것이다(Pae et al., 2010b).

본 연구에서는 수용 및 표현 어휘 검사만을 통해 두 집단을 선정한 제한점이 있기 때문에 추후 연구에서는 종합적인 언어 검사를 통해 집단을 선정하고, 이를 통해 좀 더 구체적으로 다 문화가정 아동의 담화 산출에서 비유창성이 높게 나타난 원인 을 세밀하게 살펴보는 연구가 필요할 것이다.

중심 단어 : 다문화가정의 아동·언어학적 비유창성·설명담화 · 원인-결과·비교-대조.

\section{Ethical Statement}

This study was approved by the Institutional Review Board of Chosun University (2-1041055-AB-N-01-2017-40).

\section{Acknowledgments}

The authors thank to the participants.

\section{Declaration of Conflicting Interests}

There are no conflict of interests.

\section{Funding}

N/A

\section{Author Contributions}

All authors contributed equally to this work. H.Y. and H.C. designed and performed experiments, analyzed data, and wrote the paper. Also, the authors discussed the results together and commented on the manuscript at each stage.

\section{ORCID iDs}

Hyojin Yoon

HeeCheong Chon

https://orcid.org/0000-0003-0011-2566

https://orcid.org/0000-0002-9715-7164

\section{REFERENCES}

Adams, M. R. (1990). The demands and capacities model I: Theoretical elaborations. Journal of Fluency Disorders, 15(3), 135-141.

Barron, H. D. (2018). Microlinguistic and fluency characteristics of narrative and expository discourse in adolescents with traumatic brain injury (Unpublished master's thesis). Ohio State University, Columbus, OH.

Chung, B. J. (2014). The characteristics of mazes in story and expository retelling by poor readers. Journal of Speech and Hearing Disorders, 23(1), 171-189.

Clark, H. H. \& Fox Tree, J. E. (2002). Using uh and um in spontaneous speaking. Cognition, 84(1), 73-111.

Ellis, C. \& Peach, R. K. (2009). Sentence planning following traumatic brain injury. NeuroRehabilitation, 24(3), 255-266.

Englert, C. S. \& Hiebert, E. H. (1984). Children's developing awareness of text structures in expository materials. Journal of Educational Psychology, 76(1), 65-74.

Fraundorf, S. H. \& Watson, D. G. (2013). Alice's adventures in um-derland: Psycholinguistic sources of variation in disfluency production. Language, Cognition and Neuroscience, 29(9), 1083-1096.

German, D. J. \& Newman, R. S. (2004). The impact of lexical factors on children's word-finding errors. Journal of Speech, Language, and Hearing Research, 47(3), 624-636.

Guo, L. Y., Tomblin, J. B., \& Samelson, V. (2008). Speech disruptions in the narratives of English-speaking children with specific language impairment. Journal of Speech, Language, and Hearing Research, 51(3), 722-738.

Kang, M., Hwang, M., \& Lim, J. A. (2016). Characteristics of the retelling of expository discourses by children from multicultural families according to a picture presentation condition: Focused on mazes. Special Education Research, 15(4), 163-179.

Kim, B. R. \& Yoon, H. (2018). Summarizing two expository discourses of compare-contrast and cause-effect in second, fourth and sixth graders. Communication Sciences and Disorders, 23(4), 890-901.

Kim, H. (2009). Research of the Vocabulary of Elementary School TextBooks. Seoul: National Institute of Korean Language.

Kim, J. (2004). The study of teaching program by each steps of explanatory speaking. Eomunhakkyoyuk, 28, 77-114.

Kim, K. (2003). Vocabularies for Different Levels of Korean Education. Seoul: Pagijung.

Kim, Y. T., Hong, G. H., Kim, K. H., Chang, H. S., \& Lee, J. Y. (2009). Receptive and Expressive Vocabulary Test (REVT). Seoul: Seoul Community Rehabilitation Center.

Kwon, E., Jin, Y., \& Pae, S. (2018). Korean Narrative Assessment. Seoul: Hakjisa. 
Leadholm, B. J. \& Miller, J. F. (1992). Language Sample Analysis: The Wisconsin Guide. Madison, WI: Wisconsin Department of Public Instruction.

Lee, H. \& Jung, K. H. (2013). Development of spoken and written expository discourse in school-aged children. Journal of Speech and Hearing Disorders, 22(2), 145-161.

Lee, H., Kang, J., \& Kim, H. (2010). A study on the characteristics of maze linguistic on children with specific language impairment. The Journal of Special Children Education, 12(4), 191-213.

Levelt, W. J. M. (1989). ACL-MIT Press Series in Natural-Language Processing. Speaking: From Intention to Articulation. Cambridge, MA: The MIT Press.

Lim, J. \& Hwang, M. (2009a). The characteristics of mazes in story retelling by children with attention deficit hyperactivity disorder. Communication Sciences and Disorders, 14(1), 96-108.

Lim, J. \& Hwang, M. (2009b). The developmental changes in mazes in the retelling of two types of discourse by elementary school children: A comparison between narratives and expository discourses. Communication Sciences and Disorders, 14(3), 349-362.

Loban, W. (1976). Language Development: Kindergarten Through Grade Twelve. Urbana, IL: National Council of Teachers of English.

Lundine, J. P., Harnish, S. M., McCauley, R. J., Blackett, D. S., Zezinka, A., Chen, W., et al. (2018). Adolescent summaries of narrative and expository discourse: Differences and predictors. Language, Speech, and Hearing Services in Schools, 49(3), 551-568.

Manning, W. \& Shirkey, E. (1981). Fluency and the aging process. In Beasley, D. S. \& Davis, G. A. Aging, Communication Processes and Disorders (pp. 175-189). New York, NY: Grune \& Stratton.

Navarro-Ruiz, M. I. \& Rallo-Fabra, L. (2001). Characteristics of mazes produced by SLI children. Clinical Linguistics and Phonetics, 15(1-2), 6366.

Nippold, M. A., Mansfield, T. C., \& Billow, J. L., (2007). Peer conflict explanations in children, adolescents, and adults: Examining the development of complex syntax. American Journal of Speech-Language Pathology, 16(2), 179-188.
Pae, S., Jung, K., Kim, M., \& Jin, Y. (2010a). Read and Speak Together (Unpublished Manuscript). Seoul: Ministry of Gender Equality and Family.

Pae, S. Y., Kwon, E. G., Jin, Y. S., Jun, H. J., \& Kwak, K. J. (2010b). Narratives of children with multicultural backgrounds. Journal of Speech-Language and Hearing Disorder. 19(2), 53-72.

Park, H. (2014). Korean Comprehensive Test of Nonverbal Intelligence. (2nd ed.). Seoul: Mind Press.

Peach, R. K. (2013). The cognitive basis for sentence planning difficulties in discourse after traumatic brain injury. American Journal of SpeechLanguage Pathology, 22(2), S285-S297.

Postma, A. \& Kolk, H. (1993). The covert repair hypothesis: Prearticulatory repair processes in normal and stuttered disfluencies. Journal of Speech and Hearing Research, 36(3), 472-487.

Ray, M. N. \& Meyer, B. J. F. (2011). Individual differences in children's knowledge of expository text structures: A review of literature. International Electronic Journal of Elementary Education, 4(1), 67-82.

Rispoli, M., Hadley, P., \& Holt, J. (2008). Stalls and revisions: A developmental perspective on sentence production. Journal of Speech, Language, and Hearing Research, 51(4), 953-966.

Scott, C. M. \& Windsor, J. (2000). General language performance measures in spoken and written narrative and expository discourse of school-age children with language learning disabilities. Journal of Speech, Language, and Hearing Research, 43(2), 324-339.

Thordardottir, E. T. \& Weismer, S. E. (2002). Content mazes and filled pauses in narrative language samples of children with specific language impairment. Brain and Cognition, 48(2-3), 587-592.

Wagner, C. R., Nettelbladt, U., Sahlén, B., \& Nilholm, C. (2000). Conversation versus narration in pre-school children with language impairment. International Journal of Language and Communication Disorders, 35(1), 83-93.

Westby, C., Culatta, B., Lawrence, B., \& Hall-Kenyon, K. (2010). Summarizing expository texts. Topics in Language Disorders, 30(4), 275-287.

Yairi, E. \& Seery, C. H. (2015). Stuttering: Foundations and Clinical Applications. (2nd ed.). Boston, MA: Pearson. 
APPENDIX

\section{Types of Linguistic Disfluencies}

\begin{tabular}{|c|c|c|}
\hline Types & Description & Examples \\
\hline 간투사(Filled pause) & $\begin{array}{l}\text { ‘어, 음’ 등의 음절이나 ‘뭐지’ 등의 특정 단어를 불 } \\
\text { 필요하게 사용한 경우 }\end{array}$ & 우리나라에는 (어) 명절이 있습니다. \\
\hline 휴지(Silent pause) & 발화 중간에 5 초 이상의 휴지가 있는 경우 & $\begin{array}{l}\text { 그리고 추석은 }(5 \text { 초 이상의 휴지 }) \text { 송 } \\
\text { 편을 먹습니다. }\end{array}$ \\
\hline 반복(Repetition) & $\begin{array}{l}\text { 음절, 단어나 어절, 구 등을 동일하게 되풀이하는 } \\
\text { 경우 }\end{array}$ & 비비가 많이 온다. \\
\hline 수정(Revision) & 이미 산출한 음절, 단어, 어절이나 구를 수정한 경우 & \\
\hline $\begin{array}{l}\text { 의미 및 어휘적 변화를 위한 수정 } \\
\text { (Revision for semantic and lexical } \\
\text { change) }\end{array}$ & $\begin{array}{l}\text { 이미 산출한 단어, 어절이나 구의 어휘나 의미적 정 } \\
\text { 보를 추가하기 위해 수정한 경우 }\end{array}$ & 추석에는 설날에는 떡국을 먹습니다. \\
\hline $\begin{array}{l}\text { 문법 및 구문적 변화를 위한 수정 } \\
\text { (Revision for morphosyntactic } \\
\text { change) }\end{array}$ & 이미 산출한 문법 및 구문적 오류를 수정한 경우 & $\begin{array}{l}\text { 설날에 하는 놀이를 놀이는 연날리기 } \\
\text { 입니다. }\end{array}$ \\
\hline $\begin{array}{l}\text { 음운적 변화를 위한 수정 } \\
\text { (Revision for phonological } \\
\text { change) }\end{array}$ & 이미 산출한 발화에서 음운 오류를 수정한 경우 & $\begin{array}{l}\text { 빙하가 농녹으면 바다의 물이 많아지 } \\
\text { 게 됩니다. }\end{array}$ \\
\hline
\end{tabular}

